\title{
An unexpected record of Simothraulopsis Demoulin, 1966 (Ephemeroptera, Leptophlebiidae) in the Paraná Basin, Brazil
}

\author{
Luiz R. R. Faria ${ }^{1}$, Frederico F. Salles ${ }^{2}$
}

1 Instituto Latino-Americano de Ciências da Vida e da Natureza, Universidade Federal da Integração Latino-Americana, Av. Tarquínio Joslin dos Santos, 1000, Jd. Universitário, 85.870-901, Foz do Iguaçu, PR, Brazil. 2 Museu de Entomologia, Departamento de Entomologia, Universidade Federal de Viçosa, Av. P. H. Rolfs, s/n, Campus Universitário, 36.570-900, Viçosa, MG, Brazil.

Corresponding author: Frederico Falcão Salles, ffsalles@gmail.com

\begin{abstract}
We recorded for the first time the occurrence of the mayfly genus Simothraulopsis Demoulin, 1966 in the Paraná Basin. Adults of Simothraulopsis demerara (Traver, 1947) and Simothraulopsis diamantinensis Mariano, 2010 were collected using a white sheet light trap installed on the bank of Iguaçu River, near the falls in Iguaçu National Park, Brazil. These new records significantly expand southwards the distribution of the genus.
\end{abstract}

\section{Key words}

Atalophlebiinae, biogeography, distribution, Homothraulus, Iguaçu National Park, mayfly, Parque Nacional do Iguaçu.

Academic editor: Inês Corrêa Gonçalves | Received 9 March 2019 | Accepted 17 April 2019 | Published 10 May 2019

Citation: Faria LRR, Salles FF (2019) An unexpected record of Simothraulopsis Demoulin, 1966 (Ephemeroptera, Leptophlebiidae) in the Paraná Basin, Brazil. Check List 15 (3): 375-378. https://doi.org/10.15560/15.3.375

\section{Introduction}

Knowledge concerning the systematics and distribution of the genus Simothraulopsis Demoulin, 1966 (Ephemeroptera, Leptophlebiidae) has increased considerably in the last few years with the description of several new species (Kluge 2007, Mariano 2010, Nascimento et al. 2017, Lima 2018) and a generic revision (Nascimento et al. 2017). From 1966, when the genus was described, to 2007, the distribution of Simothraulopsis was known to be restricted to a few localities in northern South America. Kluge (2007) described 2 new species from the Peruvian Amazon, Mariano (2010) and Lima (2018) described 2 new species each from northeastern Brazil, and Nascimento et al. (2017) described 4 new species mainly from northern and southeastern Brazil and provided several new records within the country.

The genus currently comprises 11 species, and its distribution ranges from the limits of Rio de Janeiro and Espírito Santo (ca $020.5^{\circ} \mathrm{S}$ ) to northern Venezuela (ca $07.5^{\circ} \mathrm{S}$ ), and from the coasts of Alagoas and Pernambuco (ca $035.3^{\circ} \mathrm{W}$ ) to the Peruvian Amazon (ca $073.4^{\circ} \mathrm{W}$ ).

In general, the species of this genus present restricted distributions. A group of species may be considered as Amazonian species (Simothraulopsis dominguezi Nascimento, Salles \& Hamada, 2017; Simothraulopsis inaequalis Nascimento, Salles \& Hamada, 2017; Simothraulopsis plesius Kluge, 2007; Simothraulopsis sabalo Kluge, 2007), while another group comprises Atlantic Forest/Cerrado species (Simothraulopsis caliginosus Nascimento, Salles \& Hamada, 2017; Simothraulopsis diamantinensis Mariano, 2010; Simothraulopsis eurybasis Nascimento, Salles \& Hamada, 2017; Simothraulopsis gracilianus Lima, 2018; Simothraulopsis sinuosus Lima, 2018). Only two species, Simothraulopsis demerara 
(Traver, 1947) and Simothraulopsis janae Mariano, 2010, are found both in Amazonia, Central Brazil, and the Atlantic Forest. For $S$. demerara, its distribution even reaches northern Venezuela (Nascimento et al. 2017).

According to Savage (1987) and Dominguez et al. (1997), and recently corroborated by Nascimento et al. (2017) and Salles and Boldrini (2019), Simothraulopsis is closely related to Homothraulus Demoulin, 1955. While the first genus is widely distributed, as mentioned above, Homothraulus is known from only a few localities in the Paraná Basin. It is noteworthy that, until now, the distributions of these genera were not known to overlap.

Based on adults collected at the Iguaçu National Park, we present the first report of $S$. demerara and $S$. diamantinensis from the Paraná Basin. These new records significantly expand southwards the known distribution of the genus.

\section{Methods}

Fieldwork was carried out in the Iguaçu River, just upstream the Iguaçu Falls, Iguaçu National Park, Brazil, in 2018. Mayfly subimagos and adults were captured with white sheet light traps from 18:00 to 22:00 h. Collected specimens were fixed in $80 \%$ ethanol. The identification of Simothraulopsis specimens were based on Mariano (2010) and Nascimento et al. (2017). Collections were made under a license issued by Instituto Chico Mendes de Conservação da Biodiversidade (ICMBio) to LRRF (\#53938). All the material is deposited in the Entomological Collection of Universidade Federal da Integração Latino-Americana (UNILA).

Previous records for the species were compiled from the following studies: (i) S. diamantinensis; Mariano 2010, Campos et al. 2017, Nascimento et al. 2017 and Costa et al. 2018; (ii) S. demerara; Traver 1947, Demou- lin 1966, Hubbard 1982, Domínguez et al. 1997, Salles et al. 2010, Lima et al. 2015, Campos et al. 2016, Lima et al. 2016, Takiya et al. 2016, Boldrini and Krolow 2017, Nascimento et al. 2017, and Costa et al. 2018. When the geographic coordinates of a given record were not made available by these authors, we used the coordinates of the municipality where the record was taken. These coordinates were obtained in an online global gazetteer (http://www.fallingrain.com/world/index.html) and the shapefile of Ottobasins presented in the distribution map was obtained in the database of ANA, the National Water Agency of Brazil (http://dadosabertos.ana.gov. br). The distribution map (Fig. 1) was made using DIVA-GIS, v. 7.5 (Hijmans et al. 2012).

\section{Results}

New records. Brazil: Paraná: Foz do Iguaçu: Parque Nacional do Iguaçu (Iguaçu River, just upstream Iguaçu Falls; $025.6927^{\circ} \mathrm{S}, 054.4331^{\circ} \mathrm{W}$ ), collected by F.F. Salles \& M. Fianco, November 24th, 2018. Simothraulopsis demerara (Figs 1A, 2A): 2 males (UNILA EP001, EP002); S. diamantinensis (Figs 1B, 2B): 7 males (UNILA EP003, EP004, EP005, EP006, EP007, EP008, EP009).

Identification. Specimens were determined using a combination of characters (for terminology of telopenis, see Kluge 2007, Salles and Boldrini 2019).

Simothraulopsis demerara: telopenis narrow (penis lobe with spine-like projection, as illustrated in Nascimento et al. 2017); inner margins of penis lobes divergent; telopenis anteriorly directed; penis lobes fused on basal third; and hind wing almost completely black.

Simothraulopsis diamantinensis: telopenis narrow; inner margins of penis lobes divergent; telopenis mesally directed; and MP fork asymmetric.

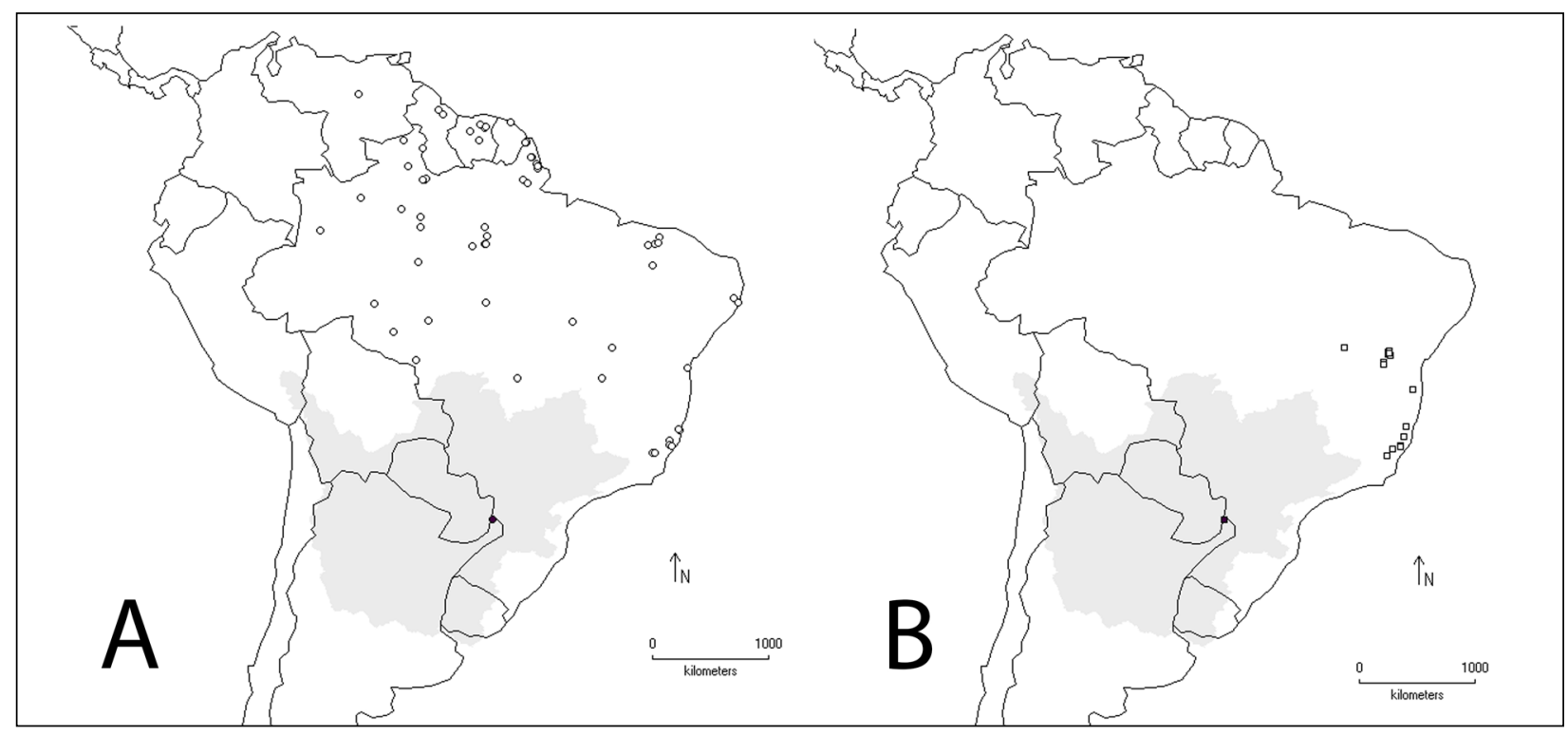

Figure 1. Distribution map of Simothraulopsis demerara and S. diamantinensis. A. S. demerara: previous records (open circles) and the new record at Iguaçu National Park (solid circle). B. S. diamantinensis: previous records (open squares) and the new record at Iguaçu National Park (solid square). The Prata/Paraná/Paraguai Ottobasin (see Methods) is presented in gray. 

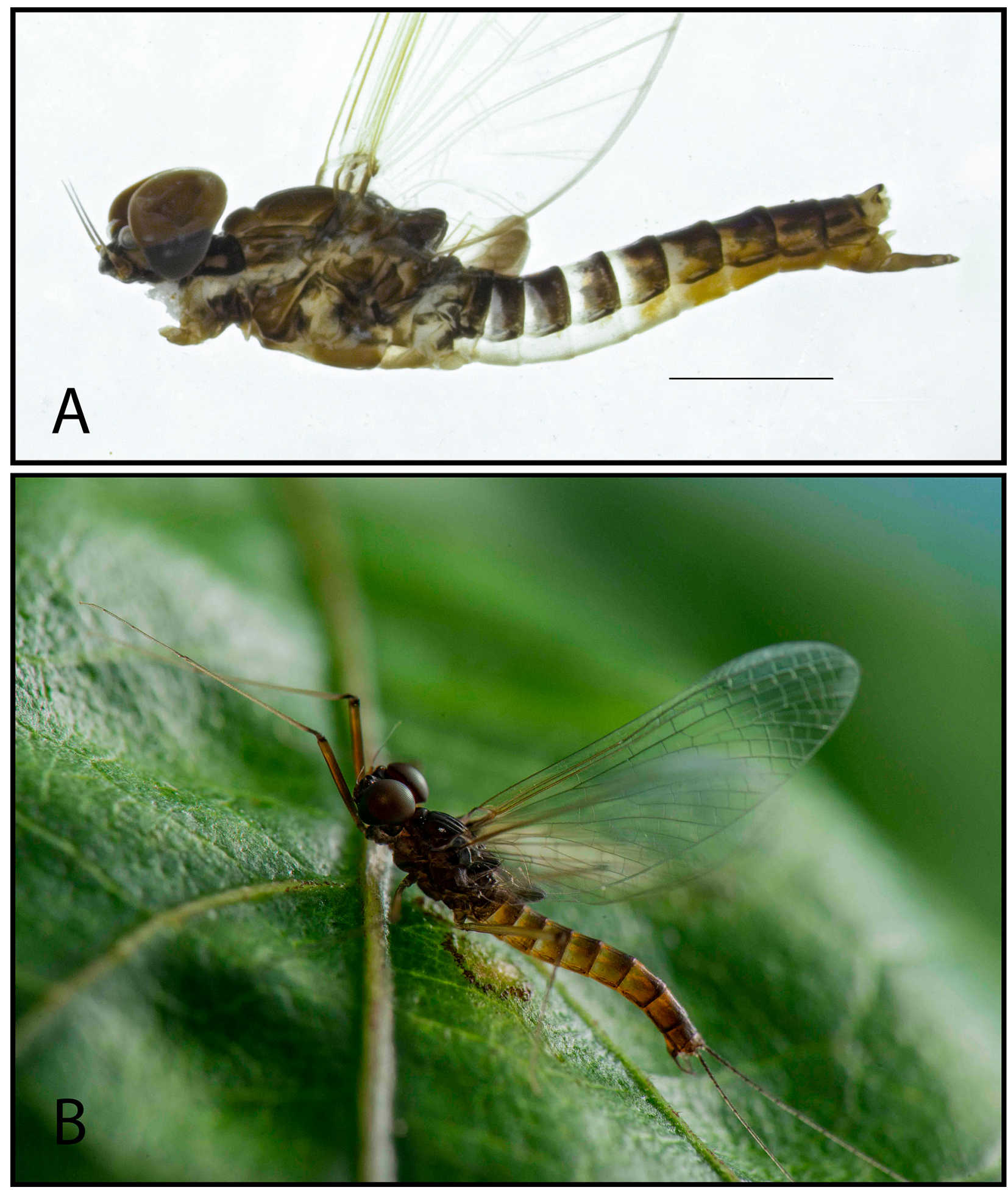

Figure 2. Simothraulopsis demerara and S. diamantinensis from the Paraná Basin. A. S. demerara, habitus. B. S. diamantinensis.

\section{Discussion}

The new records of $S$. demerara and $S$. diamantinensis represent a major expansion of the distribution of the genus to the south (ca $020.5^{\circ} \mathrm{S}$ to ca $025.7^{\circ} \mathrm{S}$ ). These records represent an expansion of ca $600 \mathrm{~km}$ from the southernmost previously known record of the genus in southern Espírito Santo state.

The new records become even more important in the context of the Paraná Basin. Among the Homothraulus lineage (see Salles and Boldrini 2019), Simothraulopsis appears as the sister group of Homothraulus (see also Domínguez 1999), a genus known from a few localities within the Paraná Basin. With the new records, all the 3 genera of the Homothraulus lineage (i.e. Farrodes Peters, 1971, Homothraulus, and Simothraulopsis) are now known to occur in the basin. In Farrodes, 1 species, Farrodes iguazuanus Domínguez \& Savage, 1987, also occurs in the Iguaçu River (Domínguez and Savage 1987).

Some intraspecific variation of both color pattern and structural differences in forewings and penis lobes are thought to occur among populations of $S$. demerara 
(Nascimento et al. 2017). However, Nascimento et al. stated that there is the possibility of sibling species within what we nowadays call $S$. demerara. One of their arguments in support of this possibility is the wide distribution of this species. Our findings reinforce the need for a phylogeographic study of $S$. demerara.

Finally, in the distribution map of $S$. demerara presented by Nascimento et al. (2017: fig. 49), they present a record of $S$. demerara near the border of Mato Grosso and Mato Grosso do Sul states, which might represent a previous occurrence in the Paraná Basin of this species. However, this record was not included in the section "material examined", which raises doubt about the information. After contacting the senior author of the paper, Dr Jeane M.C. do Nascimento (Instituto Nacional de Pesquisas da Amazônia), she was unable to locate specimens from this locality or the source for such a record. We consider, therefore, that the previous distribution of the species and genus at the Paraná Basin was a mistake.

\section{Acknowledgements}

We acknowledge J.M.C. do Nascimento who kindly provided information on the distribution map of $S$. demerara depicted in Nascimento et al. (2017). M. Fianco is acknowledged by his help during fieldwork. We thank ICMBio for providing collection permit, and PNI staff for support. National Counsel of Technological and Scientific Development from Brazil (CNPq) for a research productivity fellowship awarded to FFS. Fundação Araucária provided the stereomicroscope used for imaging the specimen in Figure 2A.

\section{Authors' Contributions}

LRRF processed collected material; FFS carried out fieldwork and identified the specimens; both authors made the plates, the distribution maps and wrote the manuscript.

\section{References}

Boldrini A, Krolow TK (2017) New records of Ephemeroptera (Insecta) from Tocantins state, northern Brazil. Check List 13 (2): 1-5. https://doi.org/10.15560/13.2.2067

Campos R, Mariano R, Calor AR (2016) Mayflies (Ephemeroptera) from Reserva Ecológica Michelin, Bahia, Brazil. Aquatic Insects 37 (4): 303-315. https://doi.org/10.1080/01650424.2016.1267769

Campos R, Mariano R, Calor AR (2017) Ephemeroptera: espécies do semi-árido. In: Bravo F (Org) Artrópodes do semi-árido II: Biodiversidade e Conservação. Métis Produção Editorial, São Paulo, 54-63.

Costa SS, Souza FN, Nogueira MAM, Santos EP, Sousa MML, Silva VA, Almeida E, Mariano R (2018) Leptophlebiidae (Insecta: Ephemeroptera) from state of Bahia, Brazil. Biota Neotropica 18 (1): e20170386. https://doi.org/10.1590/1676-0611-BN-2017-0386

Demoulin, G. (1966) Contribution à l'étude des Éphéméroptères du Surinam. Bulletin de l'Institut Royal des Sciences Naturelles de Belgique 42 (37): 1-22.
Domínguez E (1999) Systematics, cladistics and biogeography of the American genus Farrodes (Ephemeroptera: Leptophlebiidae: Atalophlebiinae). Zoological Journal of the Linnean Society 126 (2): 155-189. https://doi.org/10.1111/j.1096-3642.1999.tb00152.x

Domínguez E, Savage HM (1987) Two new species of Farrodes from continental South America with comments on the distribution of faunal components in Argentina (Ephemeroptera: Leptophlebiidae). Studies on Neotropical Fauna and Environment 22 (1): 43-52. https://doi.org/10.1080/01650528709360717

Domínguez E, Peters WL, Peters JG, Savage, HM (1997) The imago of Simothraulopsis Demoulin with a redescription of the nymph (Ephemeroptera: Leptophlebiidae: Atalophlebiinae). Aquatic Insects 19 (3): 141-150. https://doi.org/10.1080/01650429709361648

Hijmans R, Guarino L, Mathur P (2012) DIVA-GIS: Geographic Information System for Biodiversity Research. http://www.diva gis.org/. Accessed on: 2019-01-30.

Hubbard MD (1982) Catálogo abreviado de Ephemeroptera da América do Sul. Papéis Avulsos de Zoologia 34: 257-282.

Kluge NJ (2007) A new taxon Hermanellonota, or subtribe Hermanellini subtr. n. (Ephemeroptera, Leptophlebiidae, Hagenulini), with description of three new species from Peruvian Amazonia. Russian Entomological Journal 16 (4): 127-137.

Lima LRC (2018) New species of Simothraulopsis Demoulin, 1966 (Ephemeroptera: Leptophlebiidae) from Northeastern Region of Brazil. Zootaxa 4461: 253-260. https://doi.org/10.11646/zootaxa. 4461.2.6

Lima LRC, Salles FF, Pinheiro U (2015) New records of mayflies (Ephemeroptera: Insecta) from Pernambuco state, northeastern Brazil. Check List 11 (3): 1652. https://doi.org/10.15560/11.3.1652

Lima L, Knapp W, Docio L (2016) New records of mayflies (Insecta: Ephemeroptera) from Bahia state, northeastern Brazil. Entomotropica 31 (25): 212-220.

Mariano R (2010) Two new species of Simothraulopsis Traver, 1947 (Ephemeroptera: Leptophlebiidae: Atalophlebiinae) from northeastern Brazil. Aquatic Insects 32 (2): 129-134. https://doi.org/ 10.1080/01650420903393842

Nascimento JMC, Salles FF, Hamada N (2017) Systematics of Simothraulopsis Demoulin, 1966 (Ephemeroptera: Leptophlebiidae). Zootaxa 4285: 1-81. https://doi.org/10.11646/zootaxa.4285.1.1

Savage HM (1987) Biogeographic classification of the Neotropical Leptophlebiidae (Ephemeroptera) based upon geological centers of ancestral origin and ecology. Studies on Neotropical Fauna and Environment 22 (4): 199-222. https://doi.org/ $10.1080 / 01650528709360734$

Salles FF, Boldrini, R (2019) A new genus of the subtribe Hermanellina (Ephemeroptera: Leptophlebiidae: Atalophlebiinae) from northern Brazil with accounts on the systematics of the group. Insect Systematics and Evolution. https://doi.org/10.1163/1876312 X-00002300

Salles FF, Nascimento JMC, Massariol FC, Angeli KB, BarcelosSilva P, Rúdio JA, Boldrini R (2010) First survey of mayflies (Ephemeroptera, Insecta) from Espírito Santo state, southeastern Brazil. Biota Neotropica 10 (1): 293-307. https://doi.org/10.1590/ S1676-06032010000100025

Takiya DM, Santos APM, Pinto AP, Henriques-Oliveira AL, Carvalho AL, Sampaio BHL, Clarkson B, Moreira FFF, AvelinoCapistrano F, Gonçalves IC, Cordeiro IRS, Câmara JT, Barbosa JF, Souza WRM, Rafael JA (2016) Aquatic insects from the Caatinga: checklists and diversity assessments of Ubajara (Ceará State) and Sete Cidades (Piauí State) National Parks, northeastern Brazil. Biodiversity Data Journal 4: e8354. https://oi.org/ 10.3897/BDJ.4.e8354

Traver JR (1947) Notes on Neotropical mayflies. Part II. Family Baetidae, subfamily Leptophlebiinae. Revista de Entomologia 18: $149-160$. 